\title{
SURVEI KONDISI FISIK ANGGOTA UNIT KEGIATAN MAHASISWA SENAM AEROBIK PUTRI UNUSA
}

\author{
SUNANTO ${ }^{1}$, MUCHAMAD SAMSUL HUDA ${ }^{2}$ \\ ${ }^{1}$ Program Studi S1 Pendidikan Guru Pendidikan Anak Usia Dini \\ ${ }^{2}$ Program Studi S1 Pendidikan Jasmani Kesehatan dan Rekreasi \\ ${ }^{1}$ Universitas Nahdlatul Ulama Surabaya \\ ${ }^{2}$ Universitas Mulawarman Negeri Samarinda \\ Email: alif30@unusa.ac.id
}

\begin{abstract}
ABSTRAK
Senam aerobik merupakan salah satu bentuk olahraga yang banyak diminati oleh sebagian masyarakat dari golongan bawah sampai golongan atas, khususnya wanita. Baik pria maupun wanita bersama-sama melakukan senam aerobik demi memperoleh kebugaran dan kegembiraan. Pengertian senam aerobik adalah serangkaian gerak yang dipilih secara sengaja dengan cara mengikuti irama musik yang juga dipilih sehingga melahirkan ketentuan ritmis, kontinuitas dan durasi tertentu. Oleh karena itu olahraga senam aerobik juga harus dilatih kondisi fisiknya untuk meningkatkan daya tahan otot jantung, daya tahan otot lengan, daya tahan otot perut, dan kelentukan. Hal ini merupakan beberapa komponen kondisi fisik yang harus dimiliki dengan baik oleh setiap member senam aerobik. Tujuan dari penelitian ini adalah untuk mengetahui tingkat kondisi fisik anggota unik kegiatan mahasiswa senam aerobik putri Unusa. Subjek penelitian ini adalah anggota unik kegiatan mahasiswa senam aerobik putri Unusa yang diambil 20 orang. Metode dalam analisa ini menggunakan metode statistik kuantitatif deskriptif, sedangkan teknik pengumpulan data dilakukan dengan melakukan tes yang meliputi: daya tahan otot jantung, daya tahan otot lengan, daya tahan otot perut, dan kelentukan. Kesimpulan hasil penelitian. (1) Mayoritas daya tahan otot jantung anggota unik kegiatan mahasiswa senam aerobik putri Unusa adalah sangat tidak bugar. Tingkat prosentasi daya tahan otot jantung adalah $0 \%$ sangat bugar, $0 \%$ bugar, $0 \%$ di atas rata-rata $0 \%$ rata-rata, $0 \%$ di bawah rata-rata, $10 \%$ tidak bugar, dan $90 \%$ sangat tidak bugar. (2) Mayoritas daya tahan otot lengan anggota Unik kegiatan mahasiswa senam aerobik putri Unusa adalah kurang. Tingkat prosentasi adalah $0 \%$ baik sekali, $10 \%$ baik, $10 \%$ sedang, $70 \%$ kurang. Dan 10\% kurang sekali. (3) Mayoritas daya tahan otot perut anggota unik kegiatan mahasiswa senam aerobik putri Unusa adalah kurang. Tingkat prosentase adalah $0 \%$ baik sekali, $0 \%$ baik, $10 \%$ cukup, dan 90\% kurang. (4) Mayoritas kelentukan anggota unik kegiatan mahasiswa senam aerobik putri Unusa adalah kurang sekali tingkat prosentase adalah $0 \%$ baik sekali, $0 \%$ baik, $10 \%$ cukup, $20 \%$ kurang, dan $70 \%$ kurang sekali.
\end{abstract}

Kata kunci: Senam Aerobik; Kondisi Fisik; Anggota unik kegiatan mahasiswa Aerobik Unusa.

\section{PENDAHULUAN}

Olahraga adalah suatu kegiatan yang menggunakan jasmani, pikiran dan kemauan. Kegiatan ini telah ada dan berkembang di seluruh dunia. Wajarlah kalau banyak ahli yang memberikan pengertian yang berbeda, akan tetapi pada prinsipnya 
sama-sama mengarah pada kegiatan jasmani dan rohani.

Olahraga kebugaran bertujuan untuk meningkatkan daya tahan jantung, meningkatkan kekuatan otot, kelenturan tubuh, komposisi tubuh, kecepatan gerak, kelincahan dan denyut nadi (Fajriani, 2011). Olahraga kebugaran

Senam aerobik merupakan salah satu bentuk olahraga yang banyak diminati oleh sebagian masyarakat dari golongan bawah sampai golongan atas, khususnya wanita. Baik pria maupun wanita bersama-sama melakukan senam aerobik demi memperoleh kebugaran dan kegembiraan. Senam ini banyak diminati dan sifatnya yang menyenangkan, hal ini disebabkan selain gerakan-gerakannya mudah diikuti, seseorang dapat menghilangkan kepenatannya dengan musik aerobik yang begitu semangat dan enerjik.

Pengertian senam aerobik adalah serangkaian gerak yang dipilih secara sengaja dengan cara mengikuti irama musik yang juga dipilih sehingga melahirkan ketentuan ritmis, kontinuitas dan durasi tertentu (Dinata, 2007). Hal ini bertujuan untuk meningkatkan kemampuan jantung dan paru-paru serta pembentukan tubuh. Senam aerobik dilakukan secara kontinu lebih dari 4 menit dan dilakukan dengan intensitas rendah yang termasuk dalam golongan olahraga aerobik. Oleh karena itu olahraga senam aerobik juga harus dilatih kondisi fisiknya untuk meningkatkan daya tahan jantung, kekuatan otot, ketahanan otot, dan kelenturannya. Menurut (Fajriani, 2011) beberapa komponen kondisi fisik yaitu Kelentukan, Keseimbangan, Kekuatan, Kecepatan, Kelincahan,
Daya tahan, Daya ledak, Koordinasi, Ketepatan, Reaksi.

Dari beberapa komponen di atas beberapa komponen kondisi fisik utama pada cabang olahraga senam aerobik diantaranya, Ketahanan jantung, daya tahan otot lengan, daya tahan otot perut dan Kelentukan. (Dinata, 2007).

Sesuai paparan latar belakang yang diuraikan, maka peneliti ingin melakukan penelitian dengan judul "Survei Kondisi Fisik Pada Anggota UKM Senam Aerobik putri UNUSA".

Senam aerobik adalah serangkaian gerak yang dipilih secara sengaja dengan cara mengikuti irama musik yang juga dipilih sehingga melahirkan ketentuan ritmis, kontinuitas dan durasi tertentu (Dinata, 2007). Dapat disebut juga sebagai senam aerobik adalah suatu sistematika gabungan antara rangkaian gerak dan musik yang sengaja dibuat sehingga muncul keselarasan antara gerakan dan musik tersebut untuk mencapai tujuan tertentu (Ashadi, 2008).

Gerakan aerobik low impact yaitu gerakan-gerakan yang membutuhkan sebuah kaki selalu berada dilantai setiapwaktu. Sedangkan gerakan high impact yaitu mengarah pada gerakan-gerakan di mana kaki meninggalkan lantai. Impact yang memberi tekanan pada kaki adalah 3 sampai 4 kali berat badan tubuh ketika kaki kembali menginjak tanah. Tekanan ini dapat menyebabkan cedera secara tidak sengaja pada kaki, pergelangan kaki, tulang kering, dan pinggul. Tapi jika gerakan-gerakan high impact dilakukan dengan tekhnik-tekhnik yang tepat dan dikombinasikan dengan gerakan-gerakan low dan moderate impact, gerakan-gerakan 
tersebut aman, menyenagkan, dan mudah dilakukan (Brick.1994)

\section{KONDISI FISIK}

Komponen kondisi fisik adalah suatu kesatuan yang utuh dan tidak dapat dipisahkan satu dengan yang lainnya dalam upaya peningkatan dan pemeliharaan fisik. Artinya, dalam usaha peningkatan kondisi fisik, seluruh komponen tersebut harus ditingkatkan, walaupun pada praktiknya terkadang harus menerapkan sistem prioritas sesuai dengan keadaan atau prioritas kebutuhan.

Menurut (Fajriani, 2011) adapun kondisi fisik yang harus kita ketahui dan pahami, yaitu sebagai berikut:

1. Daya lentur

2. Keseimbangan

3. Kekuatan

4. Kecepatan

5. Kelincahan

6. Daya tahan yang terdiri atas:

a. Daya tahan umum

b. Daya tahan otot

7. Daya ledak

8. Koordinasi

9. Ketepatan

10. Reaksi

Menurut (Dinata, 2007) Untuk memperoleh kebugaran jasmani yang baik, harus melatih komponen dasar komponen kondisi fisik yang terdiri atas:

1. Ketahanan jantung, peredaran darah dan pernafasan

2. Ketahanan otot lengan

3. Ketahanan otot perut

4. Kelentukan

\section{METODE}

Adapun jenis penelitian yang digunakan yaitu penelitian kuantitatif dengan pendekatan deskriptif yang bertujuan untuk membuat gambaran atau lukisan secara sistematis, aktual dan akurat mengenai fakta-fakta, sifat-sifat serta hubungan antara fenomena yang diselidiki. (Nazir, 1988).

Penelitian ini menggambarkan data kondisi fisik pada anggota UKM senam aerobik putri Unusa yang mencakup dari beberapa komponen diantaranya ketahanan otot jantung (Endurance), daya tahan otot lengan, daya tahan otot perut dan kelenturan (Flexibility)

\section{HASIL ANALISIS}

Tabel 1. Hasil Perhitungan Statistik Deskriptif Tes MSFT Anggota UKM Senam Aerobik Putri Unusa.

\begin{tabular}{lccccc}
\hline & N & Min & Max & Mean & $\begin{array}{c}\text { Std. } \\
\text { Dev }\end{array}$ \\
\hline MSF & 16 & 20.00 & 24.40 & 21.9000 & 1.33467 \\
T & 16 & & & & \\
Valid & & & & & \\
N & & & & & \\
\hline
\end{tabular}

Berdasarkan pada tabel 1 di atas maka dapat diketahui bahwa daya tahan otot jantung yang diukur dengan jenis tes MSFT diperoleh nilai minimum $20.00 \mathrm{ml} / \mathrm{kg} / \mathrm{min}$, nilai maksimum $24.40 \mathrm{ml} / \mathrm{kg} / \mathrm{min}$, nilai rata - rata $21.9000 \mathrm{ml} / \mathrm{kg} / \mathrm{min}$, dan nilai standar deviasi $1.33467 \mathrm{ml} / \mathrm{kg} / \mathrm{min}$.

Tabel 2 Presentase Tes MSFT Anggota UKM Senam Aerobik Putri Unusa.

\begin{tabular}{lllll}
\hline \multicolumn{5}{c}{ Penilaian Prosentase (\%) } \\
\hline $\begin{array}{l}\text { Kurang } \\
\text { Sekali }\end{array}$ & Kurang & Sedang & Baik & $\begin{array}{l}\text { Baik } \\
\text { Sekali }\end{array}$ \\
\hline $\mathbf{1 0 0 \%}$ & $0 \%$ & $0 \%$ & $0 \%$ & $0 \%$ \\
\hline
\end{tabular}

Berdasarkan pada tabel 2 di atas maka dapat diketahui bahwa daya tahan otot jantung yang diukur dengan jenis MSFT diperoleh nilai presentase baik sekali $0 \%$, baik $0 \%$, sedang $0 \%$, kurang $0 \%$, kurang sekali $100 \%$. Berdasarkan dari tabel 2 ini, maka dapat disimpulkan nilai rata - 
rata daya tahan otot jantung anggota UKM Senam Aerobik Putri Unusa adalah kurang sekali.

Tabel 3 Statistik Deskriptif Tes Push Up Anggota UKM Senam Aerobik Putri Unusa.

\begin{tabular}{lllllc}
\hline & N & Min & Max & Mean & $\begin{array}{l}\text { Std. } \\
\text { Dev }\end{array}$ \\
\hline Push & 16 & 20.00 & 55.00 & 30.5625 & 8.4535 \\
Up & 16 & & & & 5 \\
Valid & & & & & \\
N & & & & & \\
\hline
\end{tabular}

Berdasarkan pada tabel 3 di atas maka dapat diketahui bahwa daya tahan otot lengan 1 menit diukur dengan jenis tes Push $U p$ nilai minimum 20.00 kali, nilai maksimum 55.00 kali, nilai rata - rata 30.5625 kali, dan nilai standar deviasi 8.45355 kali.

Tabel 4 Tes Push Up Anggota UKM Senam Aerobik Putri Unusa.

\begin{tabular}{lllll}
\hline \multicolumn{5}{c}{ Penilaian Prosentase (\%) } \\
\hline $\begin{array}{l}\text { Kurang } \\
\text { Sekali }\end{array}$ & Kurang & Sedang & Baik & $\begin{array}{l}\text { Baik } \\
\text { Sekali }\end{array}$ \\
\hline $\mathbf{1 0} \%$ & $70 \%$ & $10 \%$ & $10 \%$ & $0 \%$ \\
\hline
\end{tabular}

Berdasarkan pada tabel 4 di atas maka dapat diketahui bahwa daya tahan otot lengan 1 menit yang diukur dengan jenis Push up nilai presentase baik sekali $0 \%$, baik $10 \%$, sedang $10 \%$, kurang $70 \%$, dan kurang sekali $0 \%$. Berdasarkan dari tabel 4 ini, maka dapat disimpulkan nilai ratarata daya tahan otot lengan anggota UKM senam Aerobik putri Unusa adalah kurang.

Tabel 5 statistik Deskriptif Tes Sit Up Anggota UKM Senam Aerobik Putri Unusa.

\begin{tabular}{lccccc}
\hline & N & Min & Max & Mean & $\begin{array}{c}\text { Std. } \\
\text { Dev }\end{array}$ \\
\hline Sit & 16 & 10.00 & 34.00 & 17.250 & 5.9944 \\
Up & 16 & & & 0 & 4 \\
Vali & & & & & \\
d N & & & & & \\
\hline
\end{tabular}

Berdasarkan pada tabel 5 di atas maka dapat diketahui bahwa daya tahan otot perut 1 menit yang diukur dengan jenis tes Sit $U p$ nilai minimum 10,00 kali, nilai maksimum 34,00 kali, nilai rata - rata 17,2500 kali, dan nilai standar deviasi 5,99444 kali.

Tabel 6 Prosentase Tes Sit Up Anggota UKM Senam Aerobik Putri Unusa.

\begin{tabular}{cccc}
\hline \multicolumn{4}{c}{ Penilaian } \\
\hline Baik Sekali & Baik & Cukup & Kurang \\
\hline $\mathbf{9 0 \%}$ & $0 \%$ & $10 \%$ & $0 \%$ \\
\hline
\end{tabular}

Berdasarkan pada tabel 6 di atas maka dapat diketahui bahwa daya tahan otot perut 1 menit yang diukur dengan jenis Sit $U p$ nilai prosentase baik sekali $90 \%$, baik $0 \%$, cukup $10 \%$, dan kurang $0 \%$. Berdasarkan dari tabel 6 ini, maka dapat disimpulkan nilai rata-rata daya tahan otot perut anggota UKM senam Aerobik putri Unusa baik sekali.

Tabel 7 Stastik Deskriptif Tes Sit And Reach Anggota UKM Senam Aerobik Putri Unusa.

\begin{tabular}{lccccc}
\hline & N & Min & Max & Mean & $\begin{array}{l}\text { Std. } \\
\text { Dev }\end{array}$ \\
\hline Sit & 16 & 6.00 & 18.00 & 12.3250 & 2.9342 \\
And & 16 & & & & 8 \\
Reac & & & & & \\
h & & & & & \\
Valid & & & & & \\
N & & & & & \\
\hline
\end{tabular}

Berdasarkan pada tabel 7 di atas maka dapat diketahui bahwa tes duduk raih ujung kaki yang diukur dengan jenis tes Sit and Reach nilai minimum 6.00 inchi, nilai maksimum 18.00 inchi, nilai rata-rata 12.3250 inchi, dan nilai standar deviasi 2.93428 inchi. 
Tabel 8 Prosentase Tes Sit And Reach Anggota UKM Senam Aerobik Putri Unusa.

\begin{tabular}{lcccl}
\hline \multicolumn{5}{c}{ Penilaian Prosentase (\%) } \\
\hline $\begin{array}{l}\text { Kurang } \\
\text { Sekali }\end{array}$ & Kurang & Sedang & Baik & $\begin{array}{l}\text { Baik } \\
\text { Sekali }\end{array}$ \\
\hline $\mathbf{7 0} \%$ & $20 \%$ & $10 \%$ & $0 \%$ & $0 \%$ \\
\hline
\end{tabular}

Berdasarkan pada tabel $4.8 \mathrm{di}$ atas maka dapat diketahui bahwa tes duduk raih ujung kaki yang di ukur dengan jenis Sit and Reach nilai prosentase baik sekali $0 \%$ baik, $0 \%$ cukup $10 \%$, kurang $20 \%$, dan kurang sekali $70 \%$. Berdasarkan dari tabel 8 ini, maka dapat disimpulkan nilai rata-rata duduk raih ujung kaki anggota UKM senam aerobik putri Unusa kurang sekali.

\section{PEMBAHASAN}

Dalam pembahasan ini akan ditelaah data hasil penelitian tentang survei kondisi fisik anggota UKM senam aerobik putri Unusa. Sesuai dengan yang telah dijelaskan bahwa komponen kondisi fisik yang harus dimiliki oleh anggota UKM senam aerobik putri Unusa adalah daya tahan otot jantung, daya tahan otot lengan, daya tahan otot perut dan kelentukan.

Berdasarkan data hasil penelitian yang diperoleh dari anggota UKM senam aerobik Unusa, maka dapat diuraikan pembahasan sebagai berikut:

Pada komponen kondisi fisik daya tahan otot jantung anggota UKM senam aerobik putri Unusa adalah kurang. Hal ini terbukti dari hasil prosentase di bawah rata-rata mencapai $100 \%$ dan hasil prosentase kurang sekali mencapai $100 \%$. Jadi kemampuan daya tahan otot jantung anggota UKM senam aerobik putri Unusa adalah kurang sekali sehingga latihannya harus lebih ditingkatkan lagi.
Pada komponen kondisi fisik daya tahan otot lengan anggota UKM senam aerobik putri Unusa adalah kurang. Hal ini terbukti dari hasil prosentase kurang mencapai $70 \%$. Jadi kemampuan daya tahan otot lengan anggota UKM senam aerobik putri Unusa adalah kurang sehingga latihannya harus lebih ditingkatkan lagi.

Pada komponen kondisi fisik daya tahan otot perut anggota UKM senam aerobik putri Unusa adalah kurang. Hal ini terbukti dari hasil prosentase baik sekali mencapai $90 \%$ dan hasil prosentase cukup mencapai 10\%. Jadi kemampuan daya tahan otot perut anggota UKM senam aerobik putri Unusa adalah baik sekali sehingga kemampuan daya tahan otot perut nya dikatakan baik sekali.

Pada komponen kondisi fisik kelentukan anggota UKM senam aerobik putri Unusa adalah kurang sekali. Hal ini terbukti dari hasil prosentase kurang sekali mencapai $70 \%$. Jadi kemampuan kelentukan anggota UKM senam aerobik putri Unusa adalah kurang sekali sehingga latihannya harus lebih ditingkatkan lagi.

\section{KESIMPULAN}

Dari hasil dan analisisnya dapat diketahui bahwa kondisi fisik anggota UKM senam aerobik putri Unusa berbeda satu dengan yang lainnya, yang dapat dikemukakan sebagai berikut:

1. Mayoritas daya tahan otot jantung anggota UKM senam aerobik putri Unusa adalah sangat tidak bugar. Tingkat prosentasi daya tahan otot jantung adalah 0\% sangat bugar, $0 \%$ bugar, $0 \%$ di atas rata-rata $0 \%$ rata-rata, $0 \%$ di bawah rata-rata, $10 \%$ tidak bugar, dan $90 \%$ sangat 
tidak bugar.

2. Mayoritas daya tahan otot lengan anggota UKM senam aerobik putri Unusa adalah kurang. Tingkat prosentasi adalah $0 \%$ baik sekali, $10 \%$ baik, $10 \%$ sedang, $70 \%$ kurang. Dan 10\% kurang sekali.

3. Mayoritas daya tahan otot perut anggota UKM senam aerobik putri Unusa adalah kurang. Tingkat prosentase adalah $0 \%$ baik sekali, $0 \%$ baik, $10 \%$ cukup, dan $90 \%$ kurang.

4. Mayoritas kelentukan anggota UKM senam aerobik putri Unusa adalah kurang sekali tingkat prosentase adalah $0 \%$ baik sekali, $0 \%$ baik, $10 \%$ cukup, $20 \%$ kurang, dan $70 \%$ kurang sekali.

\section{SARAN}

Berdasarkan pada uraian penelitian, temuan dan simpulan di atas, maka dapat dikemukakan saran sebagai berikut:

1. Untuk daya tahan otot jantung, kemampuan daya tahan otot jantung UKM senam aerobik putri Unusa harus ditingkatkan, bahkan harus selalu berlatih secara rutin dan diharapkan harus menambah jadwal latihannya yaitu minimal 3 kali dalam seminggu sesuai dengan standar dosis latihan.

2. Untuk komponen daya tahan otot lengan, daya tahan otot perut dan kelentukan kemampuan anggota UKM senam aerobik putri Unusa perlu ditingkatkan secara bertahap.

3. Untuk mencapai kondisi fisik yang baik maka latihan fisik dilakukan secara bertahap dan terprogram serta mengikuti mengikuti standar frekuensi latihan dan tempo latihan.

4. Setiap individu anggota UKM senam aerobik putri Unusa harus dibedakan porsi latihan fisiknya sesuai kemampuan yang dimiliki.

\section{DAFTAR PUSTAKA}

Ashadi, Kunjung. 2008. Hand Out Kepelatihan Cabang Senam Aerobik I. Surabaya : JBSI FIK Unesa.

Brick, Lynne. 1994. Bugar Dengan Senam Aerobik. Rajawali Sport

Dinata, Marta. 2007. Langsing Dengan Aerobik. Jakarta : Penerbit Cerdas Jaya.

Fadillah, Rachmat. 2011. Cara Hidup Sehat. Banten : Talenta Pustaka Indonesia.

Fajriani, Wina Nurasifa. 2011. Mengenal Senam Alat. Jakarta: PT Wadah Ilmu.

Firli, Rizki. 2011. Mengenal Senam Lantai. Jakarta : PT Wadah Ilmu.

Herdiansyah, Wildan. 2011. Bulutangkis Olahraga

Kebanggaan. Jakarta : PT Wadah ilmu.

Husnul, Ade. 2011. Bergembira Melakukan Senam Irama. Jakarta : PT Wadah Ilmu.

Kemenegpora. 2006. Panduan Penetapan Parameter Tes Pada Pusat Pendidikan dan Pelatihan Pelajar dan Sekolah Khusus Olahragawan. Yogyakarta : Asisten Deputi Pengembangan SDM Keolahragaan Deputi Peningkatan Prestasi dan IPTEK Olahraga Kementerian Negara Pemuda dan Olahraga Republik Indonesia.

Mahardika, I Made Sriundy. 2008. Pengantar Evaluasi Pengajaran. Surabaya : Isori Jawa Timur.

Team. 2006. Panduan Penulisan dan Penilaian Skripsi. Surabaya : UNESA University Press. 
Jurnal Kejaora, Volume 3 Nomor 1, April 2018, ISSN 2541-5042

Sugiyono. 2010. Metode Penelitian

Kuantitatif Kualitatif dan $R$ \&

$D$. Bandung : Penerbit Alfabeta. 